\title{
Rootstocks and Grafting Interaction Studies for Gummy Stem Blight (Didymella bryoniae) and Horticultural Traits in Parthenocarpic Cucumber
}

\author{
Anjali ${ }^{1}$, Pardeep Kumar ${ }^{2}$, Parveen Sharma ${ }^{1}$, Suman Kumar ${ }^{3}$ and Vandana Thakur ${ }^{*}$ \\ ${ }^{1}$ Department of Vegetable Science and Floriculture, ${ }^{3}$ Department of Plant Pathology, CSK \\ Himachal Pradesh Krishi Vishvavidalaya, Palampur - 176 062, India \\ ${ }^{2}$ School of Life Sciences, Himachal Pradesh Central University, Dharmshala-176206, India \\ *Corresponding author
}

\section{A B S T R A C T}

\section{Keywords \\ Didymella bryoniae, Interaction, Grafting, Stem blight, Naturally ventilated polyhouse}

\section{Article Info}

Accepted:

28 July 2020

Available Online:

10 August 2020

\begin{abstract}
Vegetable grafting is known as potential technology, as to conquer biotic stresses with special emphasis on diseases resistance and to enhance the yield and biochemical properties in cucurbitaceous crops. The seven cucurbit rootstocks were screened in vitro against the disease gummy stem blight by inoculating fungus Didymella bryoniae. All the rootstocks screened unveiled resistance to the fungal pathogen Didymella bryoniae. Most of the characters under investigation were significantly influenced by the interaction effect of rootstocks and grafting techniques. Treatment RS5GT3 resulted in least number of days to first flower, days to first fruit set and minimum number of days to first fruit harvest. Whereas, RS2GT3 ensued in the highest grafting success per cent i.e. 96.67\%, highest number of marketable fruits per plant, highest marketable fruit yields per plant, maximum marketable fruit yield per square meter and maximum vine length. Treatment RS1GT3 ensued in the highest average fruit weight and fruit length. Lowest internodal length was perceived in treatment and highest TSS of was witnessed in treatment RS4GT2. The interaction effect of rootstocks and grafting techniques had no significant effect on fruit diameter and harvest duration. Therefore, it is accomplished from the study that splice grafting technique in combination with bottle gourd rootstock is found to be most apposite for attaining maximum production in terms of yield and for resistance against gummy stem blight under protected conditions.
\end{abstract}

\section{Introduction}

Recently, gummy stem blight has arisen as a severe problem in cucurbits in low hill areas of H.P like Kangra, Una, Hamirpur and Bilaspur. As the environmental conditions are changing unpredictably, it contributes to hasten the severity of this problem particularly among the farmers who so ever, growing cucurbits like bottle gourd and cucumber. Gummy stem blight is one of the utmost common diseases found worldwide in greenhouse cucumber. The main casual organism of this disease is a fungus Didymella bryoniae, earlier named as Mycosphaerella melonis and M. citrullina. The pathogen is seed borne on variety of cucurbits by Brown et al., (1970) and reported 
as soil borne by Nawaliya (2017). This pathogen infects only members of the cucurbit family such as cucumber, squash, melon, pumpkin, vegetable marrows and bitter melon. The incidence of the disease is influenced by climatic conditions (Van Steekelenburg and Vooren 1980). The fungus attacks all parts of the plant and under favorable conditions, causes severe economic losses. The disease is characterized by sudden collapse of the whole crop at the time between first fruit set and first fruit maturation. The disease causes a rapid wilt of mature plants and may lead to a total loss of the crop. No specific chemical control measure is available to control this disease. Hence, plants produced using resistant rootstocks through grafting is an effective, chemical free and an alternative technique to counter this burning problem. Grafting commercial cultivar on desirable rootstock is an effective method to decrease the harmful effects of biotic and abiotic stresses as well as improve yield and fruit quality. Canizares and Goto (1998) reported that grafting leads to increased vegetative growth, plant height and fruit quality compared to the non-grafted ones. Providing resistant rootstocks to susceptible scions prevent primary source of infection, resulting in reduced incidence of disease (Davis et al.2008). Grafting techniques and seedling stage also affect the survival and development of grafted plants. The use of grafting techniques i.e. tongues, approach, slant-cut, cleft and tube result in significant difference on plant survival rate (Rojas and Riveros, 1999). The grafting success depends on the appropriate choice for scion and rootstock combinations, use of proper grafting method and post graft management. Despite the potential of grafting for higher yields and disease control in the cultivation of cucumber and other cucurbitaceous crops, this technique has been rarely adopted and studied. No research work has been done in the past on this aspect in
Himachal Pradesh as well as in the country. Therefore, the aim of this study was to evaluate the effect of rootstocks and grafting techniques on horticultural traits and gummy stem blight in cucumber hybrid Kian. Considering all these aspects, an experiment entitled "Effect of rootstocks and grafting techniques on horticultural traits and gummy stem blight in parthenocarpic cucumber" was undertaken with the following objectives: (i) In vitro screening of different rootstocks for gummy stem blight, and to study the effect of rootstocks and grafting techniques on yield and quality attributes in cucumber.

\section{Materials and Methods}

The present study was carried out in a modified naturally ventilated polyhouse $(25 \mathrm{~m}$ x $10 \mathrm{~m}$ ) during off-season i.e. July, 2018 onwards at the Experimental Farm of Department of Vegetable Science and Floriculture. It is an ideal polyhouse with essential features like double door, side and top ventilation, drip and fogging facilities and internal shading with $50 \%$ green agro UV stabilized shade net. The climate of the area is generally sub-temperate and semi-humid with mild summers (March to June) and cool winters (October to February) with high rainfall mainly during rainy season (June to September).

\section{Experimental material and grafting techniques}

The experimental material used for the present study comprised of seven Cucurbit rootstocks of local varieties namely Summer squash, Bottle gourd, Pumpkin, Cucumber, Bitter gourd, Luffa and ash gourd; and parthenocarpic cucumber hybrid Kian as scion. The experimental design consisted of Randomized block design (RBD) with three replications. There were ten plants per treatment per replication. Three different 
grafting techniques were followed, including: Approach grafting (GT1), Hole insertion grafting (GT2) and Splice grafting (GT3). The data collection was done to know the influence rootstock and scion interactions on various yields, quality, for Gummy stem blight (Didymella bryoniae). Data was analyzed using OPSTAT software and are given in means of three replications by applying Randomized Block Design.

\section{Gummy stem blight (Didymella bryoniae) incidence $(\%)$}

The diseased samples of bottle gourd (i.e. leaves, vines, roots) were collected from district Una, Himachal Pradesh. The diseased samples were examined in the laboratory and observed microscopically to identify the associated pathogen(s). The fungal pathogen(s) were isolated by cutting the small pieces of tissue aseptically from the margins of the lesions of the fresh tissue. These bits were then disinfected for 15-20 seconds in 1\% sodium hypochlorite and were rinsed with sterile distilled water. The bits were then transferred to potato dextrose agar (PDA) medium slants under aseptic conditions and were incubated in BOD incubator at $25^{\circ} \mathrm{C}$ under 24 hours continuous photoperiod. A small piece was cut from an area of a colony to obtain a pure culture from single conidia. Fungal colony arising from single spore was multiplied on PDA for further study. Further, seven cucurbit rootstocks were screened in pot culture by inoculating Didymella bryoniae culture to know the disease reaction. Soil inoculation method was followed in which the spore suspension was prepared and poured in the soil around the rhizosphere and was kept humid at $25^{\circ} \mathrm{C}$. Disease incidence (\%) was calculated by the formula given below:

Diseaseincidence

=Numberofinfestedplants/Totalnumber of plantsplanted $\times 100$.

\section{Results and Discussion}

\section{Disease incidence}

\section{Gummy stem blight (Didymella bryoniae} incidence \%)

In present experiment seven rootstocks used in the study were inoculated with Didymella bryoniae culture in pots to screen the rootstocks for disease reaction. The examined rootstocks in pot culture did not show any incidence of fungi Didymella bryoniae. The results showed that all the rootstocks used were resistant to Didymella bryoniae incidence. It may be due to the fact that Didymella bryoniae is either a seed borne or soil borne fungi and all rootstocks were not affected by this fungal disease (Brown et al.1970, Nawaliya 2017). Whereas, as per the reports from the field hybrid varieties are highly susceptible to this pathogen (Table 1).

\section{Phenological traits}

\section{Days to first flowering}

The interaction among rootstocks and grafting techniques also significantly affected the days to first flowering (Table 2). Treatment $\mathrm{RS}_{5} \mathrm{GT}_{3}\left(\mathrm{RS}_{5}=\right.$ Bitter gourd, $\mathrm{GT}_{3}=$ Splice grafting) took minimum number of days (16.17) to first flowering which was statistically at par with treatment $\mathrm{RS}_{2} \mathrm{GT}_{2}$ (RS2 $=$ Bottle gourd, $\mathrm{GT}_{2}=$ Hole insertion grafting) which took 17.99 days. Earliness is the main index which demonstrates the significant role of the rootstock. Minimum number of days to first flower appearance recorded in grafted cucumber may be due to better scion-rootstock compatibility and better nutrient uptake. These results are in conformity with the findings of Farhadi and Malek (2015), Velkov and Pevicharova (2016) and Tamilselvi and Pugalendhi (2017). 
Table.1 Reaction of cucurbit rootstocks on the incidence of gummy stem blight (Didymella bryoniae)

\begin{tabular}{|l|l|l|}
\hline S.No. & Rootstock & Reaction \\
\hline 1. & Summer squash $\left(\mathrm{RS}_{1}\right)$ & Resistant \\
\hline 2. & Bottle gourd $\left(\mathrm{RS}_{2}\right)$ & Resistant \\
\hline 3. & Pumpkin $\left(\mathrm{RS}_{3}\right)$ & Resistant \\
\hline 4. & Cucumber $\left(\mathrm{RS}_{4}\right)$ & Resistant \\
\hline $\mathbf{5 .}$ & Bitter gourd $\left(\mathrm{RS}_{5}\right)$ & Resistant \\
\hline 6. & Luffa $\left(\mathrm{RS}_{6}\right)$ & Resistant \\
\hline 7. & Ash gourd $\left(\mathrm{RS}_{7}\right)$ & Resistant \\
\hline
\end{tabular}

Table.2 Interaction effect of rootstocks and grafting techniques on days to first flowering, days to first fruit set, days to first harvest, no. of marketable fruits per plant and marketable fruit per plant $(\mathrm{kg})$

\begin{tabular}{|l|c|c|c|c|c|}
\hline $\begin{array}{l}\text { Treatment } \\
\text { (RS×G) }\end{array}$ & $\begin{array}{c}\text { Days to } \\
\text { first } \\
\text { flowering }\end{array}$ & $\begin{array}{c}\text { Days to first } \\
\text { fruit set }\end{array}$ & $\begin{array}{c}\text { Days to first } \\
\text { harvest }\end{array}$ & $\begin{array}{c}\text { No of } \\
\text { marketable } \\
\text { fruits per } \\
\text { plant }\end{array}$ & $\begin{array}{c}\text { Marketable } \\
\text { fruit yield per } \\
\text { plant (kg) }\end{array}$ \\
\hline $\mathbf{R S}_{\mathbf{1}} \mathbf{G T}_{\mathbf{1}}$ & 21.47 & 29.07 & 37.20 & 13.87 & 1.90 \\
\hline $\mathbf{R S}_{\mathbf{1}} \mathbf{G T}_{\mathbf{2}}$ & 19.67 & 26.33 & 40.00 & 12.89 & 1.93 \\
\hline $\mathbf{R S}_{\mathbf{1}} \mathbf{G T}_{\mathbf{3}}$ & 19.00 & 25.97 & 36.22 & 13.83 & 2.21 \\
\hline $\mathbf{R S}_{\mathbf{2}} \mathbf{G T}_{\mathbf{1}}$ & 20.00 & 27.62 & 34.40 & 14.13 & 1.98 \\
\hline $\mathbf{R S}_{\mathbf{2}} \mathbf{G T}_{\mathbf{2}}$ & 17.99 & 26.53 & 36.40 & 15.67 & 2.32 \\
\hline $\mathbf{R S}_{\mathbf{2}} \mathbf{G T}_{\mathbf{3}}$ & 18.47 & 25.60 & 33.53 & 16.35 & 2.53 \\
\hline $\mathbf{R S}_{\mathbf{3}} \mathbf{G T}_{\mathbf{1}}$ & 21.23 & 28.80 & 37.47 & 12.91 & 1.92 \\
\hline $\mathbf{R S}_{\mathbf{3}} \mathbf{G T}_{\mathbf{2}}$ & 20.78 & 28.67 & 40.67 & 11.56 & 1.51 \\
\hline $\mathbf{R S}_{\mathbf{3}} \mathbf{G T}_{\mathbf{3}}$ & 21.58 & 28.28 & 36.33 & 14.48 & 2.07 \\
\hline $\mathbf{R S}_{\mathbf{4}} \mathbf{G T}_{\mathbf{1}}$ & 20.20 & 27.80 & 37.40 & 13.57 & 1.97 \\
\hline $\mathbf{R S}_{\mathbf{4}} \mathbf{G T}_{\mathbf{2}}$ & 22.67 & 29.53 & 35.47 & 14.60 & 2.05 \\
\hline $\mathbf{R S}_{\mathbf{4}} \mathbf{G T}_{\mathbf{3}}$ & 20.53 & 28.29 & 35.42 & 14.71 & 1.90 \\
\hline $\mathbf{R S}_{\mathbf{5}} \mathbf{G T}_{\mathbf{1}}$ & 19.53 & 27.13 & 36.33 & 13.27 & 1.93 \\
\hline $\mathbf{R S}_{\mathbf{5}} \mathbf{G T}_{\mathbf{2}}$ & 21.33 & 28.83 & 38.00 & 11.17 & 1.51 \\
\hline $\mathbf{R S}_{\mathbf{5}} \mathbf{G T}_{\mathbf{3}}$ & 16.17 & 24.00 & 32.89 & 12.50 & 1.73 \\
\hline $\mathbf{R S}_{\mathbf{6}} \mathbf{G T}_{\mathbf{1}}$ & 20.80 & 28.40 & 35.47 & 13.80 & 1.90 \\
\hline $\mathbf{R S}_{\mathbf{6}} \mathbf{G T}_{\mathbf{2}}$ & 22.00 & 29.00 & 36.67 & 12.17 & 1.70 \\
\hline $\mathbf{R S}_{\mathbf{6}} \mathbf{G T}_{\mathbf{3}}$ & 20.39 & 27.83 & 42.00 & 13.50 & 1.88 \\
\hline $\mathbf{R S}_{\mathbf{7}} \mathbf{G T}_{\mathbf{1}}$ & 20.62 & 29.44 & 35.89 & 13.31 & 1.68 \\
\hline $\mathbf{R S}_{\mathbf{7}} \mathbf{G T}_{\mathbf{2}}$ & 20.67 & 27.83 & 34.25 & 12.61 & 1.79 \\
\hline $\mathbf{R S}_{\mathbf{7}} \mathbf{G T}_{\mathbf{3}}$ & 22.83 & 29.77 & 35.64 & 14.16 & 2.04 \\
\hline $\mathbf{C D}_{\mathbf{P}} \mathbf{P}=\mathbf{0 . 0 5}$ & 1.85 & 2.47 & 2.58 & 1.57 & 0.25 \\
\hline
\end{tabular}


Table.3 Interaction effect of rootstocks and grafting techniques on average fruit weight $(\mathrm{g})$ and marketable fruit yield per square meter $\left(\mathrm{kg} / \mathrm{m}^{2}\right)$, fruit length $(\mathrm{cm})$, fruit diameter $(\mathrm{cm})$ and harvest duration (days)

\begin{tabular}{|c|c|c|c|c|c|}
\hline $\begin{array}{l}\text { Treatment } \\
(\mathbf{R S} \times \mathbf{G})\end{array}$ & $\begin{array}{c}\text { Average } \\
\text { fruit weight } \\
\text { (g) }\end{array}$ & $\begin{array}{l}\text { Marketable fruit } \\
\text { yield per square } \\
\text { meter }\left(\mathrm{kg} / \mathrm{m}^{2}\right)\end{array}$ & $\begin{array}{c}\text { Fruit } \\
\text { length } \\
\text { (cm) }\end{array}$ & $\begin{array}{c}\text { Fruit } \\
\text { diameter } \\
\text { (cm) }\end{array}$ & $\begin{array}{c}\text { Harvest } \\
\text { duration } \\
\text { (days) }\end{array}$ \\
\hline $\mathbf{R S}_{1} \mathbf{G T}_{1}$ & 137.26 & 9.52 & 14.40 & 4.01 & 45.73 \\
\hline $\mathbf{R S}_{1} \mathbf{G T}_{2}$ & 149.93 & 9.66 & 16.64 & 4.15 & 46.00 \\
\hline $\mathbf{R S}_{1} \mathbf{G T}_{3}$ & 160.06 & 11.05 & 17.25 & 4.03 & 46.33 \\
\hline $\mathbf{R S}_{\mathbf{2}} \mathbf{G T}_{\mathbf{1}}$ & 140.24 & 9.91 & 14.60 & 4.33 & 47.53 \\
\hline $\mathbf{R S}_{2} \mathbf{G T}_{2}$ & 147.95 & 11.58 & 14.10 & 4.28 & 50.13 \\
\hline $\mathbf{R S}_{2} \mathbf{G T}_{3}$ & 155.96 & 12.66 & 14.89 & 4.31 & 47.47 \\
\hline $\mathbf{R S}_{3} \mathbf{G T}_{1}$ & 149.94 & 9.62 & 15.00 & 3.99 & 47.42 \\
\hline $\mathbf{R S}_{3} \mathbf{G T}_{2}$ & 130.28 & 7.53 & 14.60 & 4.09 & 48.06 \\
\hline $\mathbf{R S}_{3} \mathbf{G T}_{3}$ & 142.98 & 10.36 & 14.21 & 4.05 & 47.14 \\
\hline $\mathbf{R S}_{4} \mathbf{G T}_{1}$ & 144.91 & 9.84 & 14.80 & 4.06 & 47.27 \\
\hline $\mathbf{R S}_{4} \mathbf{G T}_{2}$ & 140.20 & 10.24 & 14.09 & 4.12 & 46.67 \\
\hline $\mathrm{RS}_{4} \mathbf{G T}_{3}$ & 129.27 & 9.52 & 14.21 & 4.07 & 47.00 \\
\hline $\mathbf{R S}_{5} \mathbf{G T}_{1}$ & 145.29 & 9.63 & 14.46 & 4.05 & 47.29 \\
\hline $\mathbf{R S}_{5} \mathbf{G T}_{2}$ & 135.42 & 7.56 & 12.42 & 3.97 & 47.62 \\
\hline $\mathbf{R S}_{5} \mathbf{G T}_{3}$ & 138.33 & 8.65 & 14.33 & 4.03 & 48.33 \\
\hline $\mathbf{R S}_{6} \mathbf{G T}_{1}$ & 137.49 & 9.50 & 13.87 & 4.00 & 46.20 \\
\hline $\mathbf{R S}_{6} \mathbf{G T}_{2}$ & 139.94 & 8.51 & 13.93 & 4.07 & 48.40 \\
\hline $\mathbf{R S}_{6} \mathbf{G T}_{3}$ & 139.57 & 9.42 & 13.80 & 4.04 & 46.43 \\
\hline $\mathbf{R S}_{7} \mathbf{G T}_{1}$ & 125.76 & 8.40 & 14.79 & 4.06 & 46.27 \\
\hline $\mathbf{R S}_{7} \mathbf{G} \mathbf{T}_{2}$ & 142.35 & 8.97 & 14.43 & 4.21 & 46.50 \\
\hline $\mathbf{R S}_{7} \mathbf{G T}_{3}$ & 143.78 & 10.19 & 14.86 & 4.08 & 47.72 \\
\hline $\mathrm{CD}(\mathrm{P}=\mathbf{0 . 0 5})$ & 9.57 & 1.22 & 1.36 & NS & NS \\
\hline
\end{tabular}


Table.4 Interaction effect of rootstocks and grafting techniques on grafting success internodal length $(\mathrm{cm})$, vine length $(\mathrm{cm})$, grafting success rate $(\%)$ and TSS $\left({ }^{\circ}\right.$ Brix $)$

\begin{tabular}{|c|c|c|c|c|}
\hline Treatment & $\begin{array}{c}\text { Internodal length } \\
(\mathrm{cm})\end{array}$ & $\begin{array}{l}\text { Vine length } \\
(\mathrm{cm})\end{array}$ & $\begin{array}{c}\text { Grafting success } \\
\text { rate }(\%)\end{array}$ & TSS $\left({ }^{\circ}\right.$ Brix $)$ \\
\hline $\mathbf{R S}_{1} \mathbf{G T}_{1}$ & 10.14 & 300.00 & 73.33 & 2.07 \\
\hline $\mathbf{R S}_{1} \mathbf{G T}_{2}$ & 12.48 & 306.67 & 70.00 & 3.57 \\
\hline $\mathbf{R S}_{\mathbf{1}} \mathbf{G T}_{\mathbf{3}}$ & 10.74 & 303.33 & 66.67 & 2.50 \\
\hline $\mathbf{R S}_{\mathbf{2}} \mathbf{G} \mathbf{T}_{\mathbf{1}}$ & 10.08 & 332.00 & 86.67 & 2.43 \\
\hline $\mathbf{R S}_{\mathbf{2}} \mathbf{G T}_{\mathbf{2}}$ & 12.17 & 301.67 & 90.00 & 1.83 \\
\hline $\mathbf{R S}_{\mathbf{2}} \mathbf{G} \mathbf{T}_{\mathbf{3}}$ & 12.63 & 350.00 & 96.67 & 2.73 \\
\hline $\mathbf{R S}_{\mathbf{3}} \mathbf{G T}_{\mathbf{1}}$ & 10.80 & 320.00 & 56.67 & 2.60 \\
\hline $\mathbf{R S}_{\mathbf{3}} \mathbf{G} \mathbf{T}_{\mathbf{2}}$ & 12.58 & 326.67 & 53.33 & 3.20 \\
\hline $\mathbf{R S}_{\mathbf{3}} \mathbf{G T}_{\mathbf{3}}$ & 10.64 & 335.00 & 90.00 & 2.37 \\
\hline $\mathbf{R S}_{4} \mathbf{G T}_{1}$ & 11.49 & 313.33 & 73.33 & 1.83 \\
\hline $\mathbf{R S}_{4} \mathbf{G T}_{2}$ & 10.72 & 332.33 & 86.67 & 3.60 \\
\hline $\mathbf{R S}_{\mathbf{4}} \mathbf{G T}_{\mathbf{3}}$ & 10.94 & 328.00 & 60.00 & 2.53 \\
\hline $\mathbf{R S}_{5} \mathbf{G T}_{1}$ & 9.86 & 310.00 & 60.00 & 2.83 \\
\hline $\mathbf{R S}_{5} \mathbf{G T}_{2}$ & 10.92 & 289.33 & 60.00 & 2.40 \\
\hline $\mathbf{R S}_{5} \mathbf{G T}_{3}$ & 9.92 & 293.33 & 53.33 & 2.47 \\
\hline $\mathbf{R S}_{6} \mathbf{G T}_{\mathbf{1}}$ & 10.03 & 308.33 & 73.33 & 1.97 \\
\hline $\mathbf{R S}_{6} \mathbf{G T}_{2}$ & 9.83 & 288.33 & 53.33 & 2.50 \\
\hline $\mathbf{R S}_{6} \mathbf{G T}_{3}$ & 11.94 & 271.67 & 66.67 & 2.90 \\
\hline $\mathbf{R S}_{\mathbf{7}} \mathbf{G} \mathbf{T}_{\mathbf{1}}$ & 10.88 & 291.67 & 56.67 & 1.77 \\
\hline $\mathbf{R S}_{7} \mathbf{G} \mathbf{T}_{2}$ & 10.18 & 290.00 & 46.67 & 2.47 \\
\hline $\mathbf{R S}_{7} \mathbf{G T}_{\mathbf{3}}$ & 9.84 & 283.33 & 53.33 & 2.10 \\
\hline Control & - & - & - & 2.80 \\
\hline $\mathrm{CD}(\mathrm{P}=\mathbf{0 . 0 5})$ & 1.59 & 27.21 & 20.46 & 0.25 \\
\hline
\end{tabular}

Fig.1 Resistant rootstocks after inoculation of Didymella bryoniae

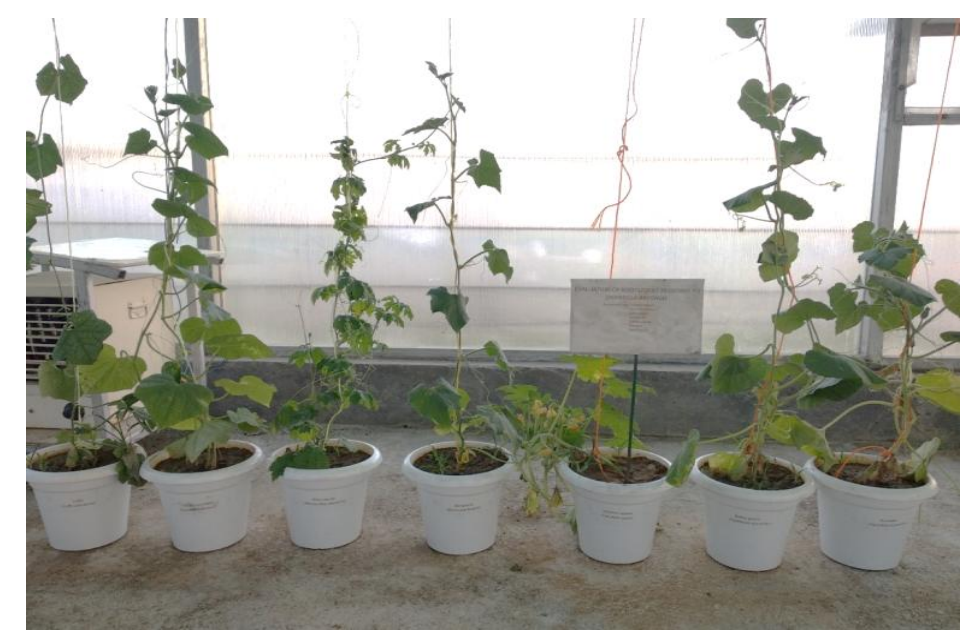




\section{Days to first fruit set}

Rootstock and scion interactions significantly affected the number of days to first fruit set. Significantly lesser number of days (24) to first fruit set were recorded in treatment RS5GT3 (RS5= Bitter gourd, GT3= Splice grafting) followed by treatments RS1GT3 (25.97 days), RS2GT3 (25.60 days) and RS1GT2 (26.33 days), which were statistically at par with treatment RS5GT3 as mentioned in Table 2.

\section{Days to first harvest}

The interactions among rootstocks and grafting techniques also resulted in significant variations for number of days to first harvest (Table 2). The treatment RS5GT3 (RS5= Bitter gourd, GT3= Splice grafting) produced fruits in significantly lesser number of days i.e. 32.89 days, followed by treatments RS2GT3 (33.53 days), RS7GT2 (34.25 days), RS2GT1 (34.40 days), RS4GT3 (35.42 days), RS6GT1 (35.47) and RS4GT2 (35.47 days), which were statistically at par with RS5GT3.

Lesser number of days taken for first fruit harvest in grafted plants may be due to ability of grafting rootstock for faster establishment and better coordination with environment. Farhadi and Rezaie (2015) also reported fruit earliness in grafted plants.

\section{Number of marketable fruits per plant}

As mention in table 2 the interaction effect of rootstock and grafting technique RS2GT3 $(\mathrm{RS} 2=$ Bottle gourd, GT3 $=$ Splice grafting $)$ produced significantly higher number of marketable fruits per plant (16.35) than all other interactions except treatment RS2GT2 (15.67) with whom it was statistically at par. Minimum number of marketable fruits per plant (11.17) were recorded in treatment RS5GT2 $($ RS5 = Bitter gourd, GT2 = Hole insertion grafting). Similar results were also obtained by Velkov and Pevicharova (2016), where they revealed that the variation in number of fruits per plant was affected more strongly by rootstock and their interaction regardless of the cucumber scion varieties.

\section{Marketable fruit yield per plant (kg)}

Interactions among rootstocks and grafting techniques also resulted in significant variations w.r.t fruit yield per plant $(\mathrm{kg})$. Maximum yield $(2.53 \mathrm{~kg})$ was noticed in RS2GT3 (RS2= Bottle gourd, GT3= Splice grafting) which was statistically at par with treatment RS2GT2 (RS2= Bottle gourd, GT2 $=$ Hole insertion grafting and RS1GT3 $(\mathrm{RS} 1=$ Summer squash, GT3= Splice grafting) with yield $2.32 \mathrm{~kg}$ and $2.21 \mathrm{~kg}$, respectively.

The lowest fruit yield $(1.51 \mathrm{~kg})$ was found in treatments RS3GT2 and RS5GT2 which was statistically at par with treatments RS7GT1 $(1.68 \mathrm{~kg})$, RS6GT2 $(1.70 \mathrm{~kg})$ and RS5GT3 $(1.73 \mathrm{~kg})$. The results presented in the table 2 indicated that rootstock 'bottle gourd' and splice grafting technique had better potential than other techniques and rootstocks used in the study.

Increase in the yield is mainly due to the increase in number of fruits per plant and average fruit weight. Similar findings were also reported by Debei et al., (2012) and Chao and Yen (2013).

\section{Average fruit weight (g)}

The interaction effects of rootstocks and grafting techniques also significantly affected the average fruit weight (Table 3). Interaction effect of treatment RS1GT3 (RS1= Summer squash, GT3= Splice grafting) resulted in the highest average fruit weight $(160.06 \mathrm{~g})$ however was statistically at par with 
treatment RS2GT3 (RS2 = Bottle gourd, GT3= Splice grafting) with average weight (155.96 g) as stated in Table 2. The results are in agreement with the findings of Khankahdani et al., (2012).

\section{Marketable fruit yield per square meter $(\mathrm{kg} / \mathrm{m} 2)$}

As per data observation as stated in table 3, interactions among rootstocks and grafting techniques, treatment RS2GT3 (RS2= Bottle gourd, GT3 $=$ Splice grafting) recorded maximum marketable fruit yield per square meter $(12.66 \mathrm{~kg} / \mathrm{m} 2)$ which was statistically at par with treatment RS2GT2 (RS2= Bottle gourd, GT2= Hole insertion grafting) with yield $(11.58 \mathrm{~kg} / \mathrm{m} 2)$ respectively. The lowest yield per square meter $(7.53 \mathrm{~kg} / \mathrm{m} 2)$ was recorded in treatment RS3GT2 (RS3= Pumpkin, GT2= Hole insertion grafting).

The best treatment combination i.e. RS2GT3 (RS2= Bottle gourd, GT3= Splice grafting) recorded $5.13 \mathrm{~kg}$ higher yield as compared to treatment combination RS3GT2 (RS3= Pumpkin, GT2= Hole insertion grafting).

The above results obtained are in agreement with those of Velkov and Pevicharova (2016) who also reported that cucumber cultivar grafted on rootstocks Lagenaria and $C$. maxima recorded the highest yield.

\section{Fruit length (cm)}

Among interactions between rootstocks and grafting techniques, treatment RS1GT3 $(\mathrm{RS} 1=$ Summer squash, GT3= Splice grafting) produced significantly longer fruits $(17.25 \mathrm{~cm})$ and was statistically at par with treatment RS1GT2 (RS1= Summer squash, GT2 $=$ Hole insertion grafting) $(16.64 \mathrm{~cm})$. Grafting techniques and their interactions with rootstocks did not affect the fruit width and harvest duration (days) (Table 3 ).

\section{Structural traits}

\section{Internodal length (cm)}

It is apparent from the data presented in the table 4 that there was a significant effect on internodal length due to the interaction effect between rootstocks and grafting techniques. Treatment RS6GT2 (RS6= Luffa, GT2= Hole insertion grafting) resulted in minimum internodal length $(9.83 \mathrm{~cm})$. The interaction effect of the rootstock luffa grafted by hole insertion technique resulted in minimum internodal length which may be due to the compatible difference of scion variety with different rootstocks. Lee and Oda (2003) also reported different responses of vegetative growth to the grafting combinations related to vigour of rootstocks and compatibility of rootstocks and scions (Fig. 1).

\section{Vine length $(\mathrm{cm})$}

As far as the interaction among rootstocks and grafting techniques is concerned significantly longer vines $(350 \mathrm{~cm})$ was recorded in treatment RS2GT3 (RS2= Bottle gourd, GT3= Splice grafting) as mentioned in table 4. Increased vine length in grafted plants may be due to the increased water and plant nutrient uptake, by the stronger and more extensive root systems of the rootstock. Similar findings recorded by Eslamboly and Deabes (2014) and Khankahdani et al., (2012) who also reported that grafting cucumber and bottle gourd on Lagenaria rootstocks resulted in significant increment in vine length.

\section{Grafting success rate $(\%)$}

As far as interaction among rootstocks and grafting techniques is concerned treatment RS2GT3 i.e. rootstock Bottle gourd with splice grafting technique recorded maximum grafting success rate $(96.67 \%)$ closely followed by treatments RS2GT2, RS3GT3, 
RS2GT1 and RS4GT2 with grafting success rate $90 \%, 90 \%, 86.67 \%$, and $86.67 \%$ respectively. Minimum grafting success rate $53.33 \%$ was observed in four treatment combinations i.e. RS3GT2, RS5GT3, RS6GT2 and RS7GT3 (Table 4), Similar trend of results was obtained by Khankahhdani et al., (2012).

\section{Quality traits}

\section{TSS $\left({ }^{\circ}\right.$ Brix $)$}

Maximum TSS of $3.60{ }^{\circ}$ Brix was observed in treatment RS4GT2 (RS4= Cucumber, GT2= Hole insertion grafting) which was statistically at par with treatment RS1GT2 $(\mathrm{RS} 1=$ Summer squash, GT2 $=$ Hole insertion grafting) with TSS of $3.57{ }^{\circ}$ Brix as specified in table 4. However TSS in both the treatments was significantly higher than TSS recorded in all other treatments. Similar findings were observed by Davis et al., (2008) and Chao and Yen (2013) who reported that the different type of rootstock alters the quality attributes of the scion fruit.Whereas, different rootstocks and grafting techniques used had no significant effect on shelf life of parthenocarpic cucumber.

In conclusion there is number of alternative techniques extant in new era, as novel developments are emerging as better means to upsurge the yield and to combat environmental stresses with ecofriendly approaches. Rootstocks and grafting techniques play a remarkable role in affecting growth, development and quality of the cucumber.

Different rootstocks used in the experiment were screened in vitro for resistance reaction to gummy stem blight, a serious disease caused by fungus Didymella bryoniae. All the rootstocks screened showed resistance to the fungal pathogen. Most of the characters under investigation were significantly influenced by interaction effect of rootstocks and grafting techniques.

\section{References}

Brown, M.E., Howard, E.M. and Knight, B.C. 1970. Seed-borne Mycosphaerella melonis on cucumber. Plant Pathology, 19: 198.

Canizares, K.A.L. and Goto, R. 1998. Growth and yield of cucumber hybrids as a result of grafting. Horticulture Brasileira , 16: 110-113.

Chao, H.F. and Yen, Y.F. 2013. Effects of Cucumis and Cucurbita rootstocks on vegetative traits, yield and quality in 'Tainan no. 1' cucumber. Journal of Horticulture Science, 8: 51-54.

Davis, A.R., Penelope, P., Richard, H., Amnon, L. and Xingping, Z. 2008. Grafting effects on vegetable quality. Horticultural Science,43: 1670-1672.

Debei, H.S.A., Makhadmeh, I., Ruz, I.A.A., Abdallat, A.M.A., Ayad, J.Y. and Amin, N.A. 2012. Influence of different rootstocks on growth and yield of cucumber (Cucumis sativus L.) under the impact of soil-borne pathogens in Jordan. Journal of Food, Agriculture and Environment, 10: 343349.

Eslamboly, A.A.S.A. and Deabes, A.A.A. 2014. Grafting cucumber onto some rootstocks for controlling root-knot nematodes. Minufia Journal of Agricultural Research, 39: 1109-1129.

Farhadi, A. and Malek, S. 2015. Evaluation of graft compatibility and organoleptic traits of greenhouse cucumber seedlings grafted on different rootstocks. Acta Horticulturae 1086: 219-224.

Farhadi, A. and Rezaie, M. 2015. Evaluation of qualitative and quantitative traits of greenhouse cucumber (Cucumis sativus 
L. 'Khassib') grafted on different Cucurbita rootstocks. Acta Horticulturae, 1086: 279-283.

Khankahdani, H.H., Zakeri, E., Saeedi, G. and Shakerdargah, G. 2012. Evaluation of different rootstocks and grafting techniques on graft union percent, yield and yield components of watermelon cv. 'Crimson Sweet'. World Applied Sciences Journal, 18: 645-651.

Lee, J.M. and Oda, M. 2003. Grafting of herbaceous vegetable and ornamental crops. Horticultural Reviews, 28: 61124.

Nawaliya, K. 2017. Etiology and management of wilt complex of Bottle gourd. M. Sc. Thesis, p 72. Department of Plant Pathology, CSKHPKV, Palampur India.

Rojas and Riveros. 1999. Effect of grafting methods and seedling age on survival and development of grafted plants in melon (Cucumis melo). Agricultura Tecnica,61: 212-274.

Tamilselvi, N.A. and Pugalendhi, L. 2017 a. Studies on effect of grafting technique on growth and yield of bitter gourd (Momordica charantia L.). Journal of Scientific and Industrial Research, 76: 654-661.

Van Steekelenburg, N.A.M. and Vooren, J. 1980. Influence of the glasshouse climate on development of diseases in a cucumber crop with special reference to stem and fruit rot caused by Didymella bryoniae. Acta Horticulturae, 118: 45-56.

Velkov, N. and Pericharova, G. 2016. Effects of cucumber grafting on yield and fruit sensory characteristics. ZemdirbysteAgriculture, 103: 405-410.

\section{How to cite this article:}

Anjali, Pardeep Kumar, Parveen Sharma, Suman Kumar and Vandana Thakur. 2020. Rootstocks and Grafting Interaction Studies for Gummy Stem Blight (Didymella bryoniae) and Horticultural Traits in Parthenocarpic Cucumber. Int.J.Curr.Microbiol.App.Sci. 9(08): 38083817. doi: https://doi.org/10.20546/ijcmas.2020.908.439 